\title{
Beyond the borders of keloid formation: A case report
}

\author{
S Cugno MSc MD, D Rizis MD, C Cordoba MD
}

S Cugno, D Rizis, C Cordoba. Beyond the borders of keloid formation: A case report. Can J Plast Surg 2011;19(1):e10-e11.

The keloid scar is a cutaneous mass characterized by nodular fibroblastic proliferation of dermis and a predilection for distinctive anatomical locations. However, keloid extension to neighbouring tissue as a nonsyndromic entity has not been described. In the present report, a case involving a 48-year-old woman with extensive bilateral keloids of the ear lobules and neck following ear piercing is presented.

Key Words: Distant scar; Ear piercing; Keloid; Neck; Scar formation

\section{Au-delà des limites de la formation de chéloïdes : un rapport de cas}

La chéloïde est une masse cutanée caractérisée par une prolifération fibroblastique nodulaire de derme et une prédilection pour des foyers anatomiques précis. Cependant, il n'existe pas de description de prolongement de chéloïdes dans les tissus avoisinants sous forme d'entité non syndromique. Dans le présent rapport, les chercheurs présentent le cas d'une femme de 48 ans ayant d'importantes chéloïdes bilatérales des lobes de l'oreille et du cou s'étant formées après un perçage d'oreilles.
A keloid is a cutaneous mass that characteristically develops following dermal injury. The keloid has beset plastic surgeons for decades, in view of both its pathological evolution and therapeutic challenges (1-4). While classically described as an overgrowth of tissue that extends beyond the borders of the original wound, extension of a

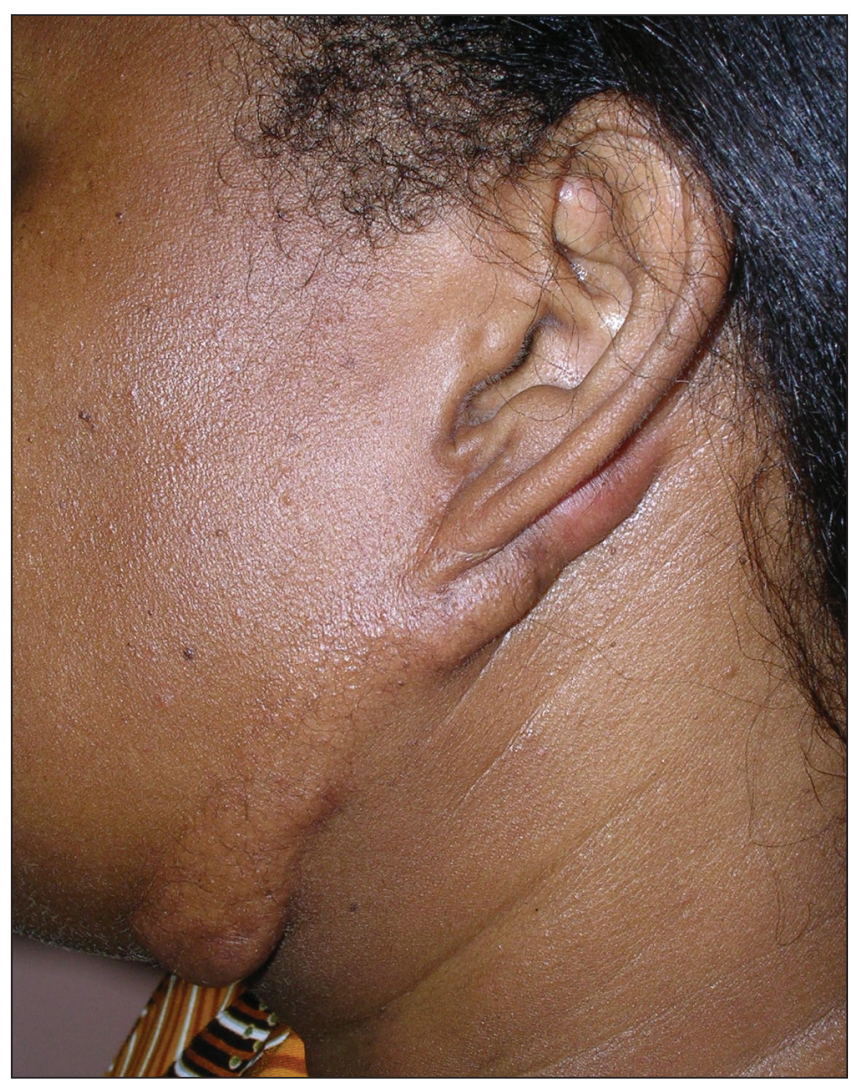

Figure 1) Lateral view of the patient. The keloid is seen extending from the ear lobule to the anterolateral aspect of the neck (the opposite side was similar in appearance) keloid to nontraumatized tissues in anatomical proximity to the wound has not been described as a characteristic feature. We discuss a case involving a woman who presented with extensive bilateral keloids on her ear lobules and neck following ear piercing.

\section{CASE PRESENTATION}

A 48-year-old black woman presented with extensive, painless, brown/ black-coloured, firm, circumscribed masses, each measuring approximately $11 \mathrm{~cm} \times 2 \mathrm{~cm}$ over the anterolateral aspects of her neck in continuity with keloidal masses on both of her earlobes of 24 years duration (Figures 1 and 2). The initial lesion developed on her earlobes following ear piercing. The evolution of disease was gradually progressive over the course of three years. At one year after the initial appearance of the ear lesions, a therapeutic excision was attempted and resulted in extending the scars to the neck region bilaterally. There was no evidence of distant scar formation or systemic involvement. The patient denied a positive family history of keloid formation or personal history of viral infection, autoimmune or other related pathological entity. The clinical differential diagnoses considered were keloid,

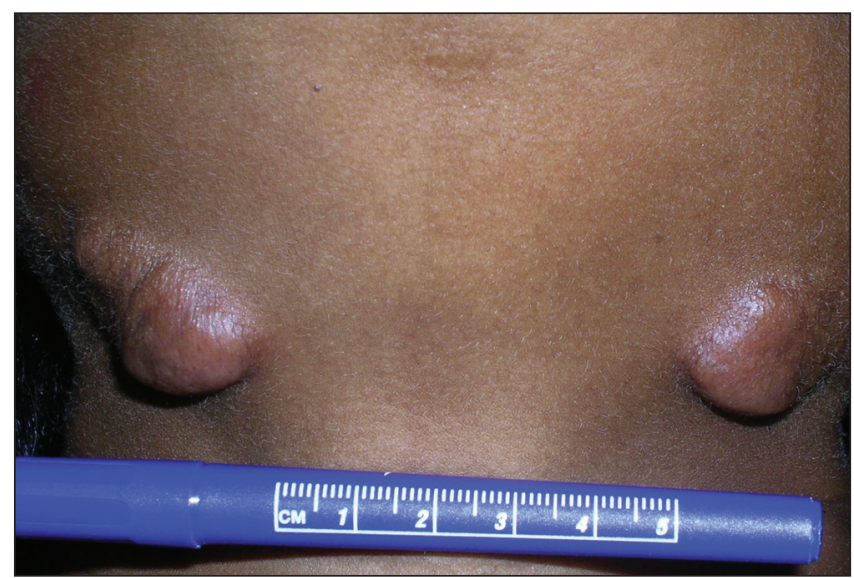

Figure 2) Anterior view of the patient. Bilateral keloidal masses on the anterolateral aspects of the neck are seen

Division of Plastic and Reconstructive Surgery, Hôpital Notre-Dame, Centre Hospitalier de l'Université de Montréal, Montreal, Quebec Correspondence: Dr Carlos Cordoba, Centre Hospitalier de l'Université de Montréal, 1560 Sherbrooke Street East, Montreal, Quebec H2L 4M1.

Telephone 514-890-8000 ext 23757, fax 514-412-7575, e-mail ccordo@hotmail.com 
granuloma faciale, lobomycosis and keloid morphea (nodular keloidal scleroderma).

Previous therapy, which consisted of local excision, resulted in keloid extension and, therefore, was not considered in further adjuvant treatment. Administration of three intralesional injections of $20 \mathrm{mg} / \mathrm{mL}$ triamcinolone acetate at three-month intervals with daily pressure therapy was given for two years, with a resultant satisfactory outcome to date.

\section{DISCUSSION}

Keloids form following dermal injury and exhibit aberrant, exuberant collagen growth. While the characteristic clinical feature of a keloid is invasion of adjacent normal dermis, appearance of satellite lesions in nontraumatized tissue has not been described in individuals without a predefined associated syndrome or genetic predisposition $(5,6)$. Our case demonstrated extensive involvement of the neck in addition to the original site of injury.

Several reports $(7,8)$ have been published that describe unusual cases of aggressive keloid formation following minor tissue trauma or irritation. Similar to the present case, these reports document atypical keloid presentation in view of both the extent and severity of the scar. However, to our knowledge, no case of keloid invasion of surrounding head and neck tissue has been documented following ear piercing and attempted localized excision.

No single unifying hypothesis adequately explains keloid formation (1-4). The numerous treatment modalities implemented for management of keloids underscores the poor understanding of keloid pathogenesis. The initial lesion in our patient failed to respond to excision alone, hence conservative management limited to intralesional corticosteroids and repeated pressure was implemented with continually progressive acceptable results.

CONFLICTS OF INTEREST: No benefits of any form have been received or will be received from a commercial party related directly or indirectly to the subject of the present article.

\section{REFERENCES}

1. Burd A. So what is a keloid? J Plast Reconstruct Aesthet Surg 2008;61:1-3.

2. Butler PD, Longaker MT, Yang GP. Current progress in keloid research and treatment. J Am Coll Surg 2008;206:731-41.

3. Robles DT, Moore E, Draznin M, Berg D. Keloids: Pathophysiology and management. Dermatol Online J 2007;13:9.

4. Leventhal D, Furr M, Reiter D. Treatment of keloids and hypertrophic scars: A meta-analysis and review of literature. Arch Facial Plast Surg 2006;8:362-8.

5. Goodfellow A, Emmerson RW, Calvert HT. Rubenstein-Taybi syndrome and spontaneous keloids. Clin Exp Dermatol 1980;5:369-70.

6. Mandal A, Imran D, Rao GS. Spontaneous keloids in siblings. Ir Med J 2004:97:250-1.

7. Bayat A, McGrouther DA, Ferguson MWJ. Clinical review article: Medicine, science and future series: Skin scarring. BMJ 2003;326:88-92.

8. Graham RM, Salem S, Baldwin AJ. Interesting case: An unusual case of keloid scarring. Br J Oral Maxillofac Surg 2006;44:244. 